\title{
Soil contamination and land subsidence raise concern in the Venice watershed, Italy
}

\author{
L. Carbognin 1 , G. Gambolati ${ }^{2}$, M. Putti ${ }^{2}$, F. Rizzetto ${ }^{1}$, P. Teatini ${ }^{2}$ \\ \& L. Tosi ${ }^{1}$ \\ ${ }^{1}$ Institute of Marine Sciences, National Research Council, Venice, Italy \\ ${ }^{2}$ Department of Mathematical Methods and Models or Scientific \\ Applications, University of Padua, Italy
}

\begin{abstract}
The southern catchment of the Venice watershed is threatened by shallow aquifer salinization and anthropogenic land subsidence due primarily to the microbial oxidation of organic soils that outcrop in the coastal farmland reclaimed from the Adriatic Sea over the last century. Recent hydrogeological and geophysical surveys provide documentary evidence that saltwater intrusion may extend inshore up to $20 \mathrm{~km}$ away from the Adriatic coastline with the contaminant plume from near ground surface down to $100 \mathrm{~m}$ depth in some areas. The actual salt distribution is the outcome of a number of factors, including the ground elevation markedly below the mean sea level (down to $-4 \mathrm{~m}$ locally), the seawater encroachment along the final $10-15 \mathrm{~km}$ of the regional watercourses (Brenta, Bacchiglione, Adige, Gorzone), and the drainage practices implemented in the reclaimed area. The fresh-salt water interface is generally between 2 and $30 \mathrm{~m}$ deep and exhibits a pronounced seasonal variation. At the same time an ongoing settlement due to peat oxidation promoted by farming activities is observed in most of the area south of the Venice Lagoon that was reclaimed from 1892 to 1967 and is rich in organic matter. Overall land subsidence over the last 70 years ranges between $1.5-2 \mathrm{~m}$ and is still in progress at a rate of $1.5-2 \mathrm{~cm} / \mathrm{y}$. As a major result a large fraction of the reclaimed land lies below the mean sea level with an increasing exposure to flooding during severe winter storms and saltwater intrusion from the Adriatic Sea, the nearby Venice Lagoon, and the river beds that locally lie above the surrounding ground surface. To mitigate both hazards the implementation of a drainage strategy of the reclaimed area intended to maintain the water table as high as possible would be required. This could decelerate the peat oxidation (hence the related land subsidence) and oppose the inland subsurface salt convection and dispersion. Moreover the design of mobile gates at a few river mouths (e.g. the Brenta river) could create an effective barrier against the seawater migration upstream the watercourses in the hottest and driest summers.

Keywords: saltwater intrusion, land subsidence, peat oxidation, soil salinization.
\end{abstract}




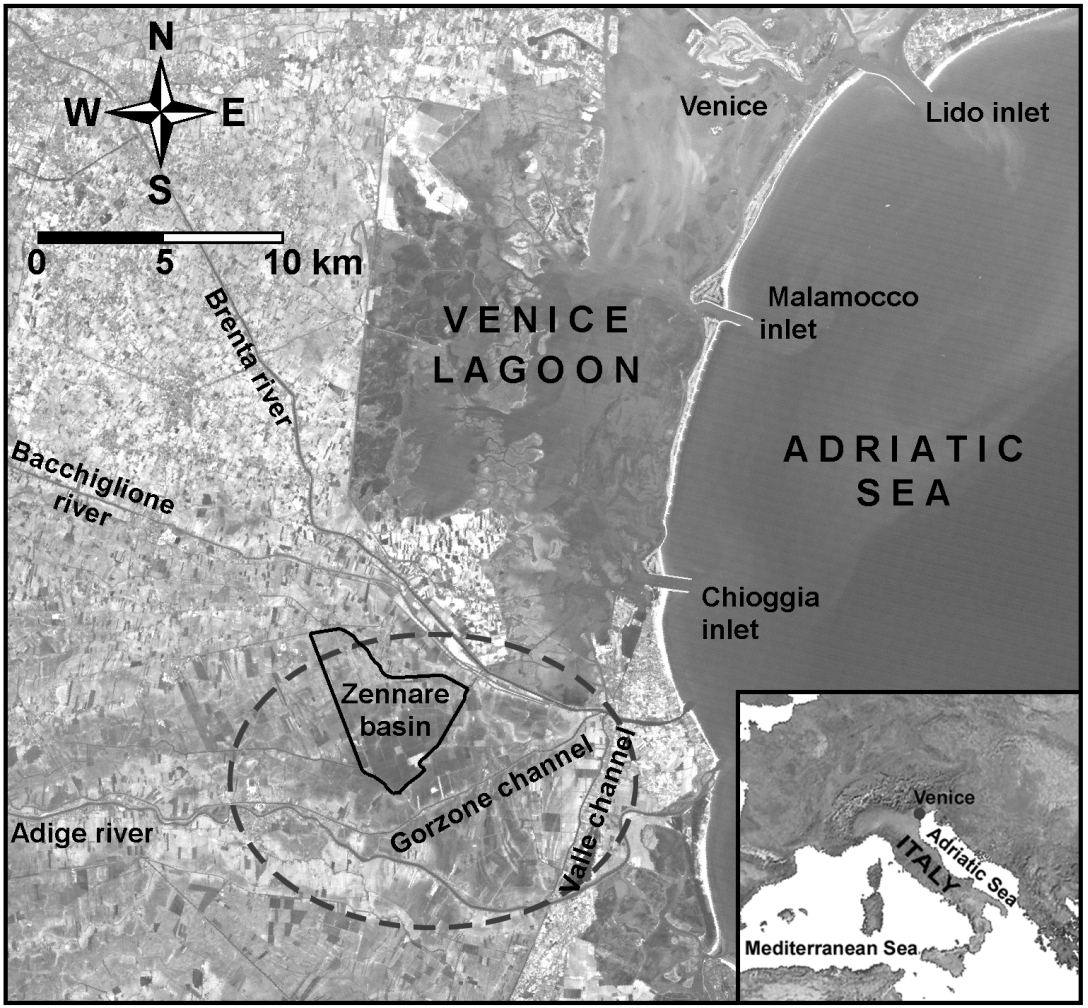

Figure 1: Map of the southern catchment of the Venice Lagoon with the location of the Zennare basin. The area characterized by outcropping organic soils (dashed line) and the major watercourses are shown.

\section{Introduction}

The Venice watershed is located in the eastern part of the Po river plain, Italy (Figure 1), and includes a very precarious coastal environment subject to both natural and anthropogenic changes. A significant and economically important fraction of the watershed is at present below the mean sea level while the reduced sediment supply to the Adriatic is impacting appreciably on the coastal morphodynamics. Venice herself is the crossroad of a number of critical problems including anthropogenic land subsidence, sea level rise, periodic flooding during severe winter storms, and lagoon water contamination of urban, industrial and agricultural origin.

Land settlement in the watershed is contributed by three different sources [1]: deep regional tectonics and natural compaction of Quaternary sediments, geomechanical compaction caused by subsurface water pumping, and biochemical oxidation of outcropping soils rich in organic matter promoted by 
farming activity (e.g., ploughing). While geomechanical subsidence in Venice seems to have come to a halt because of the well shutdown [2], natural subsidence still continues at a rate of $0.5-0.7 \mathrm{~mm} / \mathrm{y}$ [3] and geochemical subsidence in the southernmost part of the area is currently under way at an alarming rate of $1.5-2 \mathrm{~cm} / \mathrm{y}[4,5]$. At the same time the sea level is expected to rise over the present century by more than the amount $(\cong 11 \mathrm{~cm})$ experienced over the last 100 years [6]. The combined effect of sea level rise and land subsidence has enhanced the intrusion of salt water and the related soil salinization in the easternmost part of the Venice watershed.

Starting from the 70's it became evident that saline intrusion affected a large fraction of the Venice coastland. In the late 90's the problem was addressed in much detail in relation to the multiaquifer system $(50-350 \mathrm{~m})$ pumping that was the major cause of the Venice geomechanical subsidence in the 60's and early 70 's. A risk analysis was performed with the aid of numerical models for several groundwater pumping scenarios pointing to a negligible danger for the deepest aquifer units [7]. In the hydrogeologic context of the Venice coastland, the largest risk of saltwater contamination is concerned with the upper aquifers, especially in the southernmost area, because of the geomorphological setting of the coastal plain south of the Venice Lagoon [8]. Because of the serious environmental and socio-economic impacts induced by groundwater salinization, a project was undertaken in 2000 to identify area and depth involved by the presence of salinized soil that can enhance the risk of soil desertification and compromise the agricultural practices [9].

A recent research topic is concerned with the geochemical subsidence caused in the southernmost part of the Venice watershed by mass loss due to oxidation of the organic soil fraction in response to drainage for farming. Consistent with rates from 1 up to $10 \mathrm{~cm} / \mathrm{yr}$ as reported worldwide from similar processes [10], peatland settlement of the area in question amounts to $1.5-2 \mathrm{~m}$ over the last 70 years with a current rate of $1.5-2 \mathrm{~cm} / \mathrm{y}$, and more subsidence expected to occur in the future if the drainage policy is kept as it is now [4,5].

In the present communication soil contamination by saline water and geochemical land subsidence due to histosol oxidation in the Venice watershed are first reviewed with a glance at some of the most undesired consequences. Remediation strategies to alleviate or delay the processes are also outlined.

\section{Soil contamination by saline water}

Soil contamination by saline water occurs between the southern margin of the Venice Lagoon and the Adige River (Figure 1). The saltwater intrusion is connected to the geomorphological features of this area, i.e. the presence of sandy paleo-channels crossing the farmland with main direction from inland to the lagoon boundary and land elevation well below the mean sea level [8].

A research project has recently been started to map the extent of the occurrence and evaluate its criticality in relation to the economical activities of the area, i.e. mainly agriculture and horticulture. Saltwater contamination has been detected using hydrogeological and geophysical surveys and a new 
monitoring network of surface water and shallow groundwater. Namely, 700 existing stratigraphies and penetrometric tests have been analyzed and integrated with 25 new continuously sampled boreholes drilled to a depth ranging from 15 to $100 \mathrm{~m}$, and a network of about 100 monitoring wells has been established to measure the groundwater conductivity. A number of vertical electric soundings (VES) have been processed with a few electrical resistivity tomographies (ERT). Moreover, salinity measurements have been performed on surface water using 400 sampling sites to monitor the connection between drainage network and phreatic aquifer, and the tide encroachment in the river mouth [9].

With reference to the tolerance limits used in the agriculture of the study area three classes of water quality were identified:

- salty, if the water electrical conductivity $\rho$ exceeds $5000 \mu \mathrm{S} / \mathrm{cm}$ and the soil electrical resistivity $\lambda$ is less than $4.5 \mathrm{ohm} \cdot \mathrm{m}$, i.e. the seawater salinity (about $35 \mathrm{~g} / 1$ );

- brackish, if $\rho$ ranges between 2000 and $5000 \mu \mathrm{S} / \mathrm{cm}$ and $\lambda$ between 4.5 and $7 \mathrm{ohm} \cdot \mathrm{m}$ with salt concentration higher than $1 \mathrm{~g} / \mathrm{l}$ and water unsuitable for irrigation purposes;

- fresh, if $\rho$ is less than $2000 \mu \mathrm{S} / \mathrm{cm}$ and is $\lambda$ larger than $8 \mathrm{ohm} \cdot \mathrm{m}$.

Figures 2 and 3 show the depth from the ground surface of the top and bottom of the saltwater contamination plume. The top depth varies with the different hydraulic and weather conditions with the highest fluctuations occurring in the $0-10 \mathrm{~m}$ depth interval. Six depth classes equally distributed between 0 to $30 \mathrm{~m}$ are used (Figure 2). The areas belonging to the first class ( $0-5$ $\mathrm{m}$ ) are most at risk of desertification as the saltwater contamination directly involves the plant and crop root zone. High probability of land degradation characterizes the areas in the second class $(5-10 \mathrm{~m})$ as well because of the seasonal climate oscillations that can induce a transient rise of the fresh-saltwater interface. The farmland within the other classes, although somewhat sensitive to seasonal interface oscillations, is much safer in relation to saltwater contamination.

Though of less importance for the soil agricultural use, the bottom of the saltwater plume may also supplies interesting information (Figure 3), e.g. it shows the transition from the aquifer to the aquitard units. The latter act as a barrier to the downward migration of salt, thus preserving the underlying freshwater aquifers. Note that the base of the saltwater plume deepens southward, from a shallow depth of $15-30 \mathrm{~m}$ down to $60-75 \mathrm{~m}$, and locally 100 $\mathrm{m}$. The morphology of the bottom interface depends mainly on the areal distribution of the clayey layers, their permeability, as well as on thickness and continuity. Due to the evolution history of the lagoon area, wide spatial continuous impermeable layers have rarely been identified down to depth of investigation, because of the complex geologic features of this zone [8].

The time and space behavior of salt contamination is influenced by other anthropogenic factors, such as the activity of several pumping stations used to keep drained the area, groundwater withdrawals, irrigation and freshwater releases during the summer dry months. Another forcing factor that plays a primary role is the sea and lagoon tide dynamics that is responsible for 
significant saltwater encroachment into the river mouths and channels. To prevent seawater migration upstream from the river mouths during periods of low river discharge, a preliminary project for the construction of mobile gates at the mouth of the Brenta River was planned in 2004 [9]. This work which is estimated in about 15 million Euros, would generate a freshwater volume of more than $3 \times 10^{6} \mathrm{~m}^{3}$ in the terminal portion of the Brenta and Bacchiglione rivers and in the Gorzone and Valle channels (Figure 1), presently invaded by seawater.

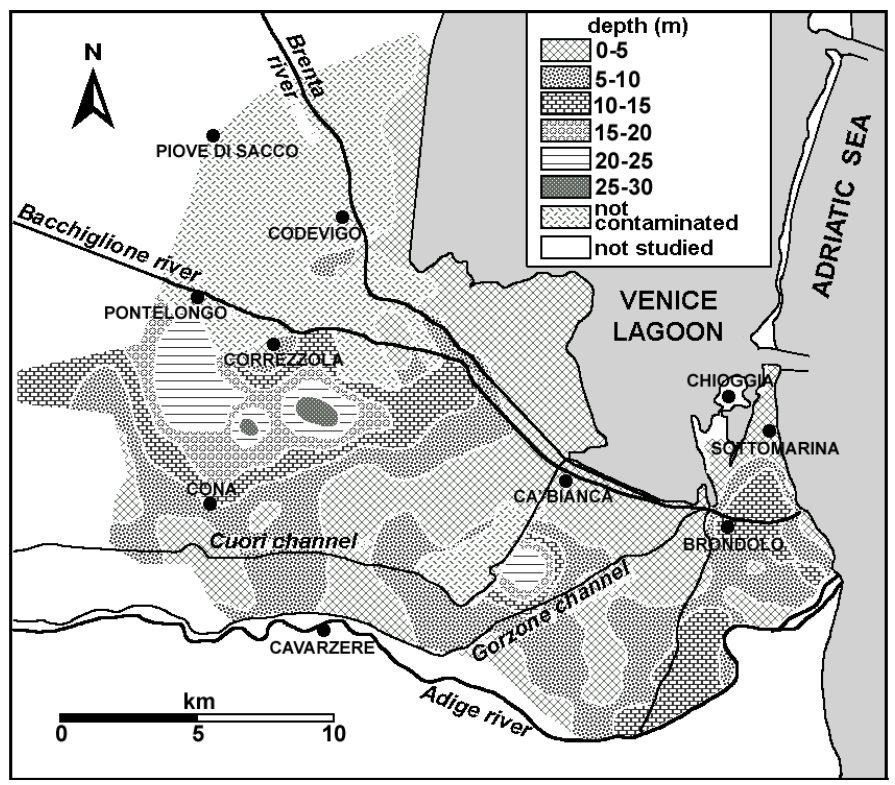

Figure 2: Depth ( $\mathrm{m}$ below the ground surface) of the top of the saltwater plume.

\section{Subsidence due to peatland oxidation}

Large areas south of the Venice Lagoon are characterized by outcropping peat (Figure 1). They were reclaimed from 1892 to 1967 and at present lie almost entirely below mean sea level. The actual depth to the water table is regulated by a complex network of ditches and pumping stations that discharge the drainage water into the Venice Lagoon or the Adriatic Sea. Flooding from the sea and the lagoon is prevented in normal conditions by levees.

When drained the soil organic fraction, generally exceeding $50 \%$ of the total volume, is subject to oxidation with $\mathrm{CO}_{2}$ release to the atmosphere, loss of sediment mass, and related land subsidence. This is demonstrated in Figure 4 with the aid of a few examples showing how some important infrastructures look like at present. The evident protrusion above the water level in the drainage network, or even above the ground surface, is a common feature of all hydraulic installations that were built at the time of the basin reclamation. The chemical 
reaction underlying the release of $\mathrm{CO}_{2}$ is primarily controlled by soil temperature and water content [10], and can be accelerated by agricultural practices, e.g. ploughing that bring to the surface deep fibrous unmineralized peat [11].

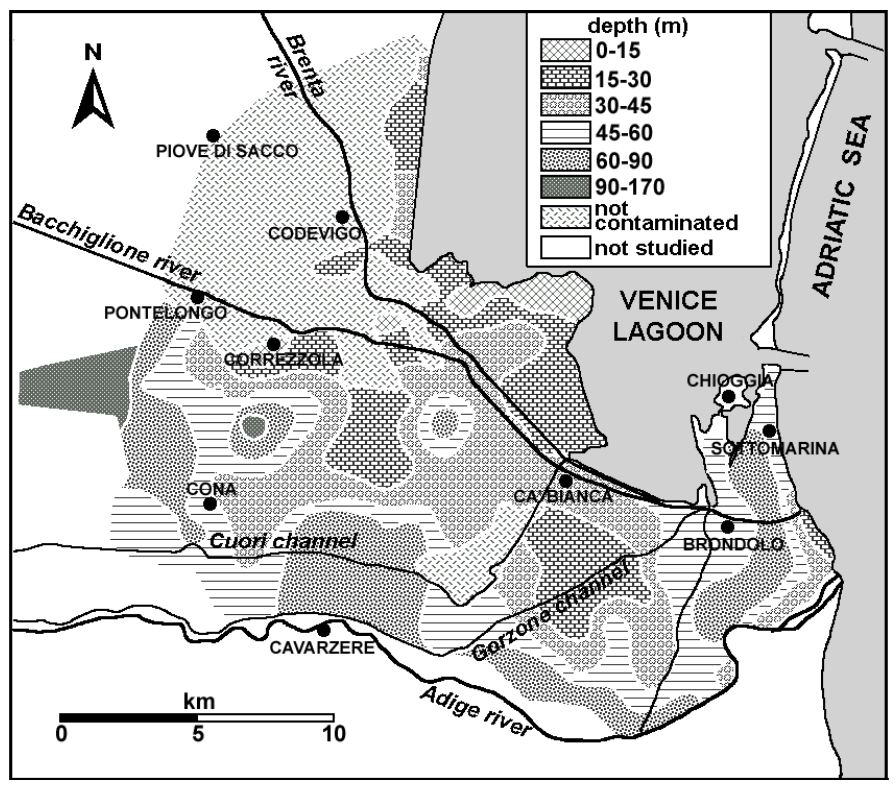

Figure 3: Depth ( $\mathrm{m}$ below the ground surface) of the bottom of the saltwater plume.

A research project called VOSS (Venice Organic Soil Subsidence) funded by Co.Ri.La was undertaken with the aim at characterizing the peat composition, defining the extent of the settling area, understanding the basic processes, and finally developing a predictive tool to help plan the most appropriate management strategies in relation to the dominant agricultural practices and the maintenance of an efficient drainage network able to safely protect the area from exceptional floods. In the VOSS mainframe, a closed catchment south of the Venice Lagoon, the Zennare basin (Figure 1), has been selected to implement the project.

The site has been instrumented with the purpose of measuring the ongoing land settlement, collecting the main hydrologic variables that control the peat oxidation (i.e. depth to water table, rainfall, soil temperature and moisture, capillary pressure) and quantifying the $\mathrm{CO}_{2}$ fluxes to the atmosphere with a NSS (Non Steady State) chamber [12]. Currently the thickness of the residual surface peat layer averages $1 \mathrm{~m}$. Prevailing sand and silty sand occur in the northernmost part of the basin with traces of old paleorivers still visible throughout the catchment. The Zennare basin lies almost entirely below mean sea level, except for a small northern corner where mineral soils are dominant. On the basis of an aerial photographic survey performed in 1983 (and never re-performed again), 
elevation ranges between -2 and $-4 \mathrm{~m}$ above mean sea level. Ground surface displacements have been measured and monitored using an ad hoc extensometer. The area extent of peatland has been investigated by satellite data. Several images from IKONOS, ASTER, and LANDSAT-7ETM+ satellites, which combine high geometric $\left(1 \mathrm{~m}^{2}\right.$ for IKONOS) and high spectral (6 bands for LANSAT and 14 for ASTER) resolution, have been analysed and calibrated against available geomorphologic maps and a large dataset of peat spectral signatures collected in situ with a portable spectrometer. The peat areas detected in this way compare nicely with an 1833 map of the local marshes drawn by government officials of the Lombardo-Veneto kingdom [7].
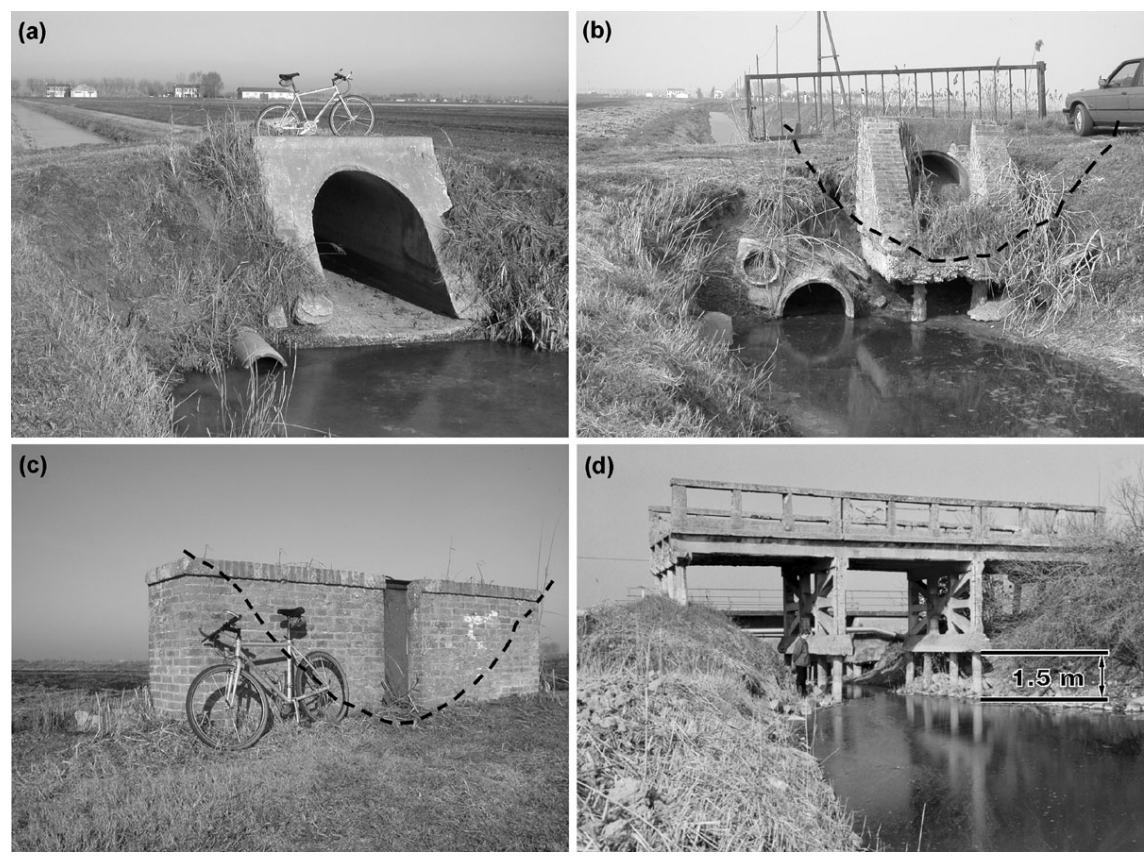

Figure 4: Evidence of the anthropogenic land subsidence in the reclaimed area. (a) A bridge has been turned into a useless structure: the left drainpipe helps convey the water of the channel originally flowing through the protruding infrastructure. (b) An old masonry culvert presently above the water level and substituted by two lower concrete drainpipes, the higher of which already unusable. A qualitative position of the ditch section in the original configuration is sketched. (c) The protrusion of a sluice wall above the bed of an old disappeared channel. (d) An old bridge hanging over the canal bank that settled by $1.5 \mathrm{~m}$.

Although ad hoc campaigns to measure land subsidence in the Zennare basin were never performed before 2000, a number of independent factors point to an average long-term subsidence rate of 2-3 cm/y. Land subsidence estimated from 
1964 to 1983 by the reclamation authority with the aid of elevation maps suggest that locally a maximum settlement approaching $1 \mathrm{~m}$ was measured near the northwestern and the southwestern Zennare boundaries. The Zennare pumping station provides indirect evidence of the surface sinking experienced in the area. The shaft level of the station that drains off the surplus water from the basin has been lowered from the original 1930 elevation by approximately $1.5 \mathrm{~m}$ [5]. Comparing the 1983 DEM with the outcome of a DGPS (Differential Global Positioning System) survey carried out in 2002 shows that some points have settled at a rate of $4-5 \mathrm{~cm} / \mathrm{y}$, consistent with the area peat distribution detected from satellites. On the average a $1.5-2 \mathrm{~m}$ of subsidence has affected the basin over the last 70 years with a present trend equal to $1.5-2 \mathrm{~cm} / \mathrm{y}$. Figure 5 gives the local vertical land displacement measured by the extensometer from January 2002 to December 2003. Note the highly fluctuating and irregular behaviour pointing to the superposition of different processes, including the important elastic peat response to rainfall (mire breathing) and soil freezing. However, a general trend is clearly distinguishable and indicates $2 \mathrm{~cm}$ over the two year observation period. The $\mathrm{CO}_{2}$ efflux measured with the NSS chamber ranges between 0.2 and $0.7 \mathrm{mgr} \mathrm{m}^{-2} \mathrm{~s}^{-1}$ corresponding to subsidence rates that are in good agreement with the direct displacement records.

Finally, a prediction based on the model by Stephen et al's [10] indicates that if the 2003 temperatures are projected into the future, the presently existing peat layer is bound to disappear completely in about 65 years for a constant $60 \mathrm{~cm}$ depth to the water table with an additional $75-100 \mathrm{~cm}$ of subsidence expected over the next half century. By distinction if a $20 \mathrm{~cm}$ water table depth is constantly maintained, 200 years would be required to totally oxidize the land peat. To become an effective management strategy, a shallower phreatic surface calls for innovative agricultural practices along with an accurate and timely control of the drainage system and the pumping stations, possibly with the aid of forecasting models.

\section{Conclusion}

Water and land management over the last decades has triggered two undesired occurrences in the southern Venice watershed: saltwater contamination of the phreatic and shallowest confined aquifers and geochemical land subsidence. The combined effect of both processes is producing an alarming social and environmental impact on the coastland addressed by the present study, also in relation to the expected global climate change.

Although the area is not experiencing everywhere the saline contamination, a very serious situation has been brought to light in a large portion of the coastal farmland. The fresh/saltwater interface is very close to the ground surface, between 0 to $10 \mathrm{~m}$, with the thickness of the upper freshwater lenses often on the order of $1 \mathrm{~m}$, depending on drainage and weather conditions. The saltwater contamination plume extends up to $20 \mathrm{~km}$ inshore and is enhanced by land elevation, generally below the mean sea level, the geomorphological structures of the coastal plain, and the seawater encroachment along the hanging last 
portion of the watercourses. A cumulative land settlement of more than $1 \mathrm{~m}$ over the past 70 years has been observed in many places. The oxidation of the soil organic matter accounts for a present subsidence rate of 1.5-2.0 $\mathrm{cm} / \mathrm{y}$ to which other less relevant factors, e.g. neotectonics, natural consolidation of the sedimentary column and groundwater pumping, superpose.

Mitigation of both hazards is of paramount importance. A number of strategies are under investigation, i.e. 1- the careful implementation of an ad hoc drainage management to maintain the water table as high as possible; $2-$ the control of seawater upstream migration from the river mouths by mobile gates; 3 - the use of conservative tilling as a substitute to ploughing to decrease the exposure of new unmineralized peat to atmosphere; and 4- the introduction of cover crops that may partially offset the loss of organic material thus yielding a reduction of the present anthropogenic land subsidence rate.

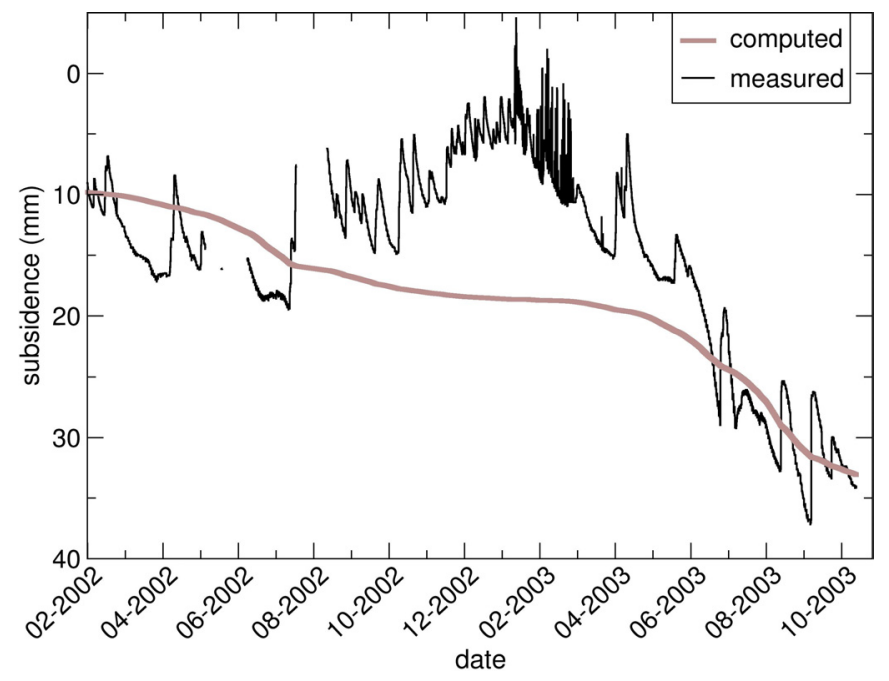

Figure 5: Comparison between computed and measured land subsidence since February 2002 after ice melting.

\section{Acknowledgments}

The work has been supported by Co.Ri.La., Subprojects 3.1 and 3.10, and ISES Project.

\section{References}

[1] Carbognin, L., Teatini, P. \& Tosi, L., Land Subsidence in the Venetian area: known and recent aspects. Giornale di Geologia Applicata, 1, pp. 5-11, 2005. 
[2] Brambati, A., Carbognin, L., Quaia, T., Teatini P. \& Tosi, L., The Lagoon of Venice: geological setting, evolution and land subsidence. Episodes, 26(3), pp. 264-268, 2003.

[3] Bortolami, G., Carbognin, L. \& Gatto, P., The natural subsidence in the Lagoon of Venice, Italy. Land Subsidence, eds. A.I. Johnson et al., IAHS Publ. no. 151, pp. 777-785, 1985.

[4] Gambolati G. et al., Peatland oxidation enhances subsidence in the Venice watershed. EOS-Trans. Amer. Geoghys. Union, 86(23), pp. 217-224, 2005.

[5] Gambolati, G., Putti, M., Teatini, P. \& Gasparetto Stori, G., Subsidence due to peat oxidation and impact on drainage infrastructures in a farmland catchment south of the Venice Lagoon. Environ. Geology, 49(6), pp. 814820, 2006.

[6] Carbognin, L., Teatini, P. \& Tosi, L., Relative land subsidence in the lagoon of Venice, Italy, at the beginning of the new millennium. J. Marine Systems, 51(1-4), pp. 345-353, 2004.

[7] Bixio, A.C., Putti, M., Tosi, L., Carbognin, L. \& Gambolati, G., Finite element modeling of salt water intrusion in the Venice aquifer system. Computational Methods in Surface and Ground Water Transport, eds. V.N. Burganos et al., vol. 2, Computational Mechanics and Elsevier Applied Sciences: Suthampton, UK, pp. 193-200, 1998.

[8] Rizzetto, F., Tosi, L., Carbognin, L., Bonardi, M. \& Teatini, P., Geomorphological setting and related hydrogeological implications of the coastal plain south of the Venice Lagoon (Italy). Hydrology of the Mediterranean and Semiarid Regions, eds. E. Servat et al., IAHS Publ. n. 278: Wallingford, UK., pp. 463-470, 2003.

[9] Carbognin, L., Rizzetto, F., Tosi, L., Teatini, P. \& Gasparetto-Stori, G., L'intrusione salina nel comprensorio lagunare veneziano. Il bacino meridionale. Giornale di Geologia Applicata, 2, pp. 119-124, 2005.

[10] Stephens, J. C., Allen Jr., L. A. \& Chen, E., Organic soil subsidence. Man-Induced Land Subsidence, ed. T. Holzer, Rev. Eng. Geol., Geological Society of America: Boulder, Colorado, VI, pp. 107-122, 1984.

[11] Andriesse, J.P., Nature and Management of Tropical Peat Soils, FAO Soils Bulletin 59, 1988.

[12] Hutchinson, G.L. \& Rochette P., Non-flow-through steady-state chambers for measuring soil respiration: Numerical evaluation of their performance. Soil Sci. Soc. Am. J., 67, pp. 166-180, 2003. 